Brit.F. vener. Dis. (1968), 44, 324.

\title{
OCCURRENCE OF T-STRAINS AND OTHER MYCOPLASMATA IN NON-GONOCOCCAL URETHRITIS*
}

\author{
BY
}

\author{
F. T. BLACK AND O. G. RASMUSSEN \\ From the Institute of Medical Microbiology, University of Aarhus (Chief: E. A. Freundt), and the \\ Dermato-Venereological University Clinic of Marselisborg Hospital, Aarhus
}

(Chief: E. Lomholt), Denmark

In spite of the constantly increasing interest taken in the disease, it has not yet been possible to clarify the aetiology of non-specific, non-gonococcal urethritis.

Dienes and Edsall (1937) isolated a strain of mycoplasma from a patient with a Bartholin's gland abscess, and this became a prelude to numerous studies in which attempts were made to demonstrate the aetiological significance of mycoplasmata in inflammatory conditions of the lower genito-urinary tract, including particularly non-gonococcal urethritis (NGU). However, the results obtained were widely different, with isolation rates ranging from 7 per cent. (Salaman, King, Bell, Wilkinson, Gallagher, Kirk, Howorth, and Keppich, 1946) to 53 per cent. (Shepard, 1954). Freundt (1956) found mycoplasma species in the urethra in 53.6 per cent. of 28 healthy men, as compared with only 30 per cent. and 50 per cent. in patients with NGU and sub-clinical NGU. In addition, when KlienebergerNobel (1959) found a higher incidence of mycoplasmata in the male urethra in patients with gonorrhoea (48 per cent.) than in those with NGU (26 per cent.), it became difficult to continue to accept the possible significance of classic mycoplasma strains as an aetiological factor in NGU, even though the importance of differences in the mode of selection of patients and methods of investigation could not be overlooked. However, at the present time, most investigators seem to be inclined to interpret the classic mycoplasma strains ("large-colony strains") as saprophytes or commensals in the male urethra. It should be noted that the isolated strains in nearly all cases in which typing was performed were Mycoplasma homonis.

Shepard (1954) observed, among typical mycoplasma colonies, some minute colonies, which he called $\mathrm{T}$-strain mycoplasma ( $\mathrm{T}$ for tiny). However, Klieneberger-Nobel (1959) queried the classification

* Received for publication May 3, 1968. of T-strains as mycoplasmata and Shepard's observation also met with scepticism in other quarters.

Ford and Macdonald (1963) none the less, by 1962, showed that the concept of T-strains as an independent mycoplasma group was accepted.

Since then, the $T$-strains have attracted much attention, and Shepard (1959), Ford, Rasmussen, and Minken (1962), Ford and DuVernet (1963), Shepard, Alexander, Lunceford, and Campbell (1964), Csonka, Williams and Corse (1966) and Ingham, Macfarlane, Hale, Selkon, and Codd (1966) have published excellent studies on the occurrence of $T$-strains both in patients with NGU and gonorrhoea and in healthy controls (Table I, opposite).

In patients with gonorrhoea the isolation rates of T-strains range from 13 per cent. (Shepard and others, 1964) to 61 per cent. (Ingham and others, 1966). In patients with NGU, the above-mentioned group of investigators reported isolation rates ranging from 52 per cent. to 79 per cent., as against 13 per cent. to 48 per cent. in the control groups. Only in one study (Csonka and others, 1966) was a significant difference disclosed between NGU and the control group, with isolation rates of 70 per cent. and 13 per cent., respectively. The smallest difference between NGU and a control group, with frequencies of 66 per cent. and 48 per cent., respectively, was found by Ingham and others (1966).

Even though the observed tendency to a more frequent occurrence of T-strains in NGU is suggestive of an aetiological relationship, the differences in numbers of patients, criteria for selection, methods of investigation and cultivation, and not least in choice of control groups are so conspicuous that further investigations are required. As far as we know, the study of Freundt (1956) is the most recent Danish report on the isolation of mycoplasma species from the male urethra. This has prompted us to present new Danish case material with particular reference to the possible pathogenic role of $T$-strains in NGU. 
TABLE I

SUMMARY OF PREVIOUS INVESTIGATIONS OF T-STRAINS IN THE MALE URETHRA

\begin{tabular}{|c|c|c|c|c|c|c|c|c|c|c|c|c|}
\hline \multirow{3}{*}{ Authors } & \multirow{3}{*}{ Date } & \multicolumn{3}{|c|}{ Gonorrhoea } & \multicolumn{3}{|c|}{ NGU } & \multicolumn{5}{|c|}{ Controls } \\
\hline & & \multirow{2}{*}{$\begin{array}{l}\text { No. of } \\
\text { Cases } \\
\text { Studied }\end{array}$} & \multicolumn{2}{|c|}{ T-strains } & \multirow{2}{*}{$\begin{array}{l}\text { No. of } \\
\text { Cases } \\
\text { Studied }\end{array}$} & \multicolumn{2}{|c|}{ T-strains } & \multirow{2}{*}{$\begin{array}{l}\text { No. of } \\
\text { Cases } \\
\text { Studied }\end{array}$} & \multirow{2}{*}{ Groups Examined } & \multirow{2}{*}{$\begin{array}{c}\text { Source } \\
\text { of } \\
\text { Specimen }\end{array}$} & \multicolumn{2}{|c|}{ T-strains } \\
\hline & & & No. & Per cent. & & No. & Per cent. & & & & No. & Per cent. \\
\hline Shepard & 1956 & & & & 74 & 46 & 62 & & & & & \\
\hline Shepard & 1959 & & & & 650 & & 70 & & & & & \\
\hline \multirow[t]{2}{*}{$\begin{array}{l}\text { Ford and } \\
\text { Macdonald }\end{array}$} & \multirow[t]{2}{*}{1963} & \multirow[t]{2}{*}{27} & \multirow[t]{2}{*}{7} & \multirow[t]{2}{*}{26} & \multirow[t]{2}{*}{45} & \multirow[t]{2}{*}{27} & \multirow[t]{2}{*}{60} & 25 & $\begin{array}{l}\text { Inmates of city } \\
\text { gaol }\end{array}$ & Urethra & 7 & 28 \\
\hline & & & & & & & & 30 & $\begin{array}{l}\text { Patients without } \\
\text { earlier genito- } \\
\text { urinary disease }\end{array}$ & Urethra & 5 & 17 \\
\hline $\begin{array}{l}\text { Ford and } \\
\text { DuVernet }\end{array}$ & 1963 & & & & 100 & 79 & 79 & 100 & Service recruits & Urethra & 21 & 21 \\
\hline $\begin{array}{l}\text { Shepard and } \\
\text { others }\end{array}$ & 1964 & 139 & 18 & 13 & 64 & 33 & 52 & & & & & \\
\hline $\begin{array}{l}\text { Csonka and } \\
\text { others }\end{array}$ & 1966 & $\begin{array}{c}50 \\
\text { followed } \\
\text { by NGU } \\
13\end{array}$ & $\begin{array}{l}14 \\
10\end{array}$ & $\begin{array}{l}28 \\
77\end{array}$ & $\begin{array}{c}101 \\
\text { Reiter } \\
+\underset{7}{N G U} \\
\end{array}$ & $\begin{array}{l}71 \\
6\end{array}$ & 70 & 95 & $\begin{array}{l}\text { Healthy men } \\
\text { (Doctors, etc.) }\end{array}$ & Urine & 12 & 13 \\
\hline $\begin{array}{l}\text { Ingham and } \\
\text { others }\end{array}$ & 1966 & 36 & 22 & 61 & 45 & 30 & 66 & 54 & $\begin{array}{l}\text { Men seeking re- } \\
\text { assurance that } \\
\text { they had not } \\
\text { contracted } \\
\text { venereal disease }\end{array}$ & Urethra & 26 & 48 \\
\hline
\end{tabular}

\section{Material (275 men)}

\section{Patients (125)}

Men who attended the Dermato-Venereological University Clinic at Marselisborg Hospital, Aarhus, from January 1, 1966, to February 28, 1967. This clinic is open to all persons who want to be examined or treated for venereal disease, but the clientèle consists almost exclusively of members of the local population. Socially, there is apparently a certain preponderance of the lower classes of the population, as it seems that the higher social classes tend to apply for treatment to private venereologists.

Group I Patients with non-specific, non-gonococcal urethritis ( 56 cases; average age 25 years). These were men with mucous or muco-purulent discharge and sometimes moderate dysuria, but in whom microscopy and the culture of urethral discharge failed to reveal gonococci or trichomonads.

Group II Patients with gonococcal urethritis (60 cases; average age 25 years). The diagnosis was proved by microscopy and culture.

Group III Patients with balanitis erosiva and balanoposthitis without urethral discharge ( 9 cases; average age 24 years).

\section{Controls (150)}

Group 1 Healthy contacts of patients with gonorrhoea ( 46 subjects; average age 24 years). Socially, this group corresponded closely to the three groups of patients.

Group 2 Recently called-up service recruits with no history or sign of urethritis ( 53 subjects; ages from 18 to 24 years).
Group 3 Physicians and a few technicians from the departments in which the investigations were carried out (16 subjects; ages from 29 to 48 years). None of these presented signs of urethritis.

Group 4 Medical students without clinical signs of urethritis ( 35 subjects; average age 24 years).

\section{Methods}

In the patients and control Group 1 urethral scrapings were obtained by means of a metal probe. The material was streaked on to micro-slides and stained with methylene blue with a view to evaluation of the leucocyte and bacterial content, especially Neisseria gonorrhoeae. The patient was then requested to void urine, and a sterile cotton-tipped swab was inserted $2-3 \mathrm{~cm}$. into the urethra. In addition, a sample was placed in Stuart's transport medium and sent to the State Serum Institute, Copenhagen, for culture for N. gonorrhoeae.

In the control Groups 2, 3, and 4 urethral scrapings were not obtained before the voiding of urine.

Wet, unstained smears were examined for Trichomonas vaginalis by direct microscopy. In the initial phase of the investigation attempts were made to employ previously described methods for cultivation (Freundt, 1954), but without success.

For mycoplasma isolations the swab was immediately placed in a transport medium consisting of heart infusion broth (Difco) to which was added 20 per cent. swine serum (but not antibiotics or thallium acetate). The specimen was then stored at $4^{\circ} \mathrm{C}$. for 24 or, at most $48 \mathrm{hrs}$, after which it was subcultured after not more than $2 \mathrm{hrs}$ ' transport. This method was used instead of direct 
inoculation in the department because sufficient facilities for storage and incubation of the media used were not available at the hospital. In some cases, cultures for mycoplasma from urine were made simultaneously with the inoculation of urethral discharge. An amount of 10 ml. urine was then passed directly into a sterile glass tube and centrifuged at 3,000 r.p.m. for 15 minutes, after which the supernatant was pipetted off, and cultivation was performed from the remaining (approx.) $0.5 \mathrm{ml}$.

\section{Isolation of Classic Mycoplasmata}

The following media were used:

(1) PPLO broth and PPLO agar (Difco) to which were added 20 per cent. horse serum, 10 per cent. yeast extract (baker's yeast), thallium acetate $1: 3000$, and sodium penicillin, $400 \mathrm{i} . \mathrm{u} . / \mathrm{ml}$.

(2) The medium as above, but with the addition of nucleotide (calf thymus, Sigma) to a concentration of 0.002 per cent.

From the transport medium, $0.1 \mathrm{ml}$. was transferred to fluid medium, which was incubated for 3 days at $37^{\circ} \mathrm{C}$. and then subcultured on a solid medium of the same composition. The plates were incubated in candle jars at $37^{\circ} \mathrm{C}$. for 6 days, after which they were read under a stereomicroscope $(\times 50)$ without preceding staining.

The classic mycoplasmata were identified by the growth-inhibition test.

\section{Isolation of T-Strains}

Agar media of the following three compositions were used:

(1) $S$ medium A slightly modified Shepard medium consisting of trypticase-soy broth (Baltimore Biological Laboratory) 3 per cent., Ionagar No. 2 (Oxoid) $1 \cdot 13$ per cent., horse serum 30 per cent., and sodium penicillin, 1500 i.u. $/ \mathrm{ml}$.

Before the serum was added, the solution was adjusted to $\mathrm{pH} 6 \cdot 0$; after the addition the $\mathrm{pH}$ was approx. $6 \cdot 2$.

(2) $S N$ medium The same as $S$ medium, but with addition of nucleotide solution (calf thymus, Sigma) to a concentration of 0.002 per cent.

(3) $S T$ medium The same as $S$ medium, but with thallium acetate added to a concentration of $1: 1500$.

From the transport medium, material was plated directly on to the agar media, which were incubated in a 20 per cent. $\mathrm{CO}_{2}$ atmosphere at $37^{\circ} \mathrm{C}$. for 3 days. Previous studies (unpublished data) have shown that this atmosphere of cultivation is iust as suitable for the isolation of $\mathrm{T}$-strains as that recommended by Ford and Macdonald (1963), consisting of 80 per cent. $\mathrm{N}_{2}$ and 20 per cent. $\mathrm{CO}_{2}$.

All agar plates were studied under a stereomicroscope without preceding staining. The $T$-strains were primarily separated from the classic mycoplasmata only on the basis of their characteristic colonial morphology. The size of the colonies could not always be used as a criterion for separation, as $\mathrm{T}$-strains with colonies measuring up to $175 \mu$ were often observed at the primary isolation. Subsequently, all isolated T-strains were tested for their ability to utilize urea (Shepard and Lunceford, 1967), by which the primary classification as $\mathrm{T}$-strains was confirmed in all cases.

\section{Results}

Influence of the Methods of Cultivation on the Results

Storage of Inoculation Material In cultures of material from 53 subjects (control Group 2), the results of direct inoculation of growth medium, followed by incubation at $37^{\circ} \mathrm{C}$., were compared with those obtained when the swab had been left in transport medium at $4^{\circ} \mathrm{C}$. for 2 days. Table II shows that the results obtained by the two methods were practically identical with regard to the isolation rates of both $\mathrm{T}$-strains and $M$. hominis.

TABLE II

COMPARISON OF RESULTS OF CULTIVATION IN 53 SUBJECTS (CONTROL GROUP 2) OBTAINED BY DIRECT INOCULATION IN THE HOSPITAL AND AFTER STORAGE IN TRANSPORT MEDIUM AT $+4^{\circ} \mathrm{C}$. FOR 2 DAYS

\begin{tabular}{|c|c|c|c|c|}
\hline \multirow{2}{*}{$\begin{array}{c}\text { Condition } \\
\text { of Cultivation }\end{array}$} & \multicolumn{2}{|c|}{ T-strains } & \multicolumn{2}{|c|}{ M. hominis } \\
\hline & No. & Per cent. & No. & Per cent. \\
\hline $\begin{array}{l}\text { Direct Inoculation } \\
\text { Storage in Transport } \\
\text { Medium } \\
\text { at }+4^{\circ} \mathrm{C} \text {. for } 2 \text { days }\end{array}$ & $\begin{array}{l}31 \\
30\end{array}$ & $\begin{array}{l}58 \cdot 5 \\
56 \cdot 6\end{array}$ & $\begin{array}{l}5 \\
5\end{array}$ & $\begin{array}{l}9 \cdot 2 \\
9 \cdot 2\end{array}$ \\
\hline
\end{tabular}

Simultaneous Cultures of Urethral Discharge and Urine In the 53 subjects from control Group 2, isolation was attempted from urethral discharge and from urine at the same time. The results are listed in Table III, which shows that T-strains were isolated much more frequently from urethral discharge ( 58.5 per cent.) than from urine $(15 \cdot 1$ per cent.). $T$-strains were never isolated from urine without being simultaneously recovered from urethral discharge. The difference is statistically significant. $(\mathrm{P}<0.001) . M$. hominis was isolated in only a small number of cases, but with nearly equal frequency from urethral discharge and urine.

TABLE III

ISOLATION RATES FROM URETHRA AND URINE CONTROL GROUP 2

\begin{tabular}{l|c|c|c|c}
\hline \multirow{2}{*}{ Material } & \multicolumn{2}{|c|}{ T-strains } & \multicolumn{2}{c}{ M. hominis } \\
\cline { 2 - 5 } & No. & Per cent. & No. & Per cent. \\
\hline Urethral & 31 & $58 \cdot 5$ & 5 & $9 \cdot 2$ \\
$\begin{array}{l}\text { Ucraping (swab) } \\
\text { Urine }\end{array}$ & 8 & $15 \cdot 1$ & 4 & $7 \cdot 6$ \\
\hline
\end{tabular}

Variations in the Composition of the Growth Medium The two media which were used for the isolation of $M$. hominis and $M$. fermentans gave no definite difference in the isolation rates. Thus the addition of nucleotide did not seem to exert any influence on the growth of these species. On the other 
hand, the special media used for the $\mathrm{T}$-strains were found to be unsuited for the isolation of classic mycoplasmata. Among the 65 inoculations which yielded growth on PPLO medium (Difco) with horse serum, only 39 were positive on the Shepard media.

The results of the isolation of $T$-strains on the three different modifications of the Shepard medium are listed in Table IV. Growth of T-strains was obtained on one or more of the media used in a total of 234 swabs. In 74 cases, maximum growth, with regard to both number and size of the colonies and growth rate, was observed on the $S$ medium, whereas no growth occurred in nineteen cases. The $\mathrm{SN}$ medium yielded the best growth in 46 and no growth in 35 cases. Finally, the ST medium gave good growth in only thirteen and no growth in 65 cases.

\section{TABLE IV}

COMPARISON OF RESULTS OF CULTIVATION IN THREE DIFFERENT T-STRAIN MEDIA AS OBTAINED IN A TOTAL OF 234 POSITIVE SWABS

\begin{tabular}{l|c|c|c}
\hline \multicolumn{1}{c|}{ Medium } & Shepard & $\begin{array}{c}\text { Shepard }+ \\
\text { nucleotide }\end{array}$ & $\begin{array}{c}\text { Shepard }+ \\
\text { thallium } \\
\text { acetate }\end{array}$ \\
\hline $\begin{array}{l}\text { Maximum growth } \\
\begin{array}{l}\text { Growth on one } \\
\text { medium only }\end{array}\end{array}$ & 74 & 46 & 13 \\
No growth & 14 & 5 & 4 \\
\hline
\end{tabular}

Isolation of Mycoplasmata from Patient and Control Groups

As appears from Table $\mathrm{V}$, large-colony strains (classic mycoplasmata) were, in the first attempt at cultivation, demonstrated in $19 \cdot 6$ per cent. of 56 patients with NGU, in 26.7 per cent. of sixty patients with gonorrhoea, and in 33 per cent. of nine patients with balanoposthitis. In control Group 1, which with regard to social conditions and sexual activity and hygiene must be said to correspond best to the patient groups, large-colony strains were demonstrated in 37 per cent. of 46 subjects examined. The isolation rates in control Groups 2, 3, and 4 were appreciably lower.

In nearly all cases, the isolated strains were classified as $M$. hominis by the growth-inhibition test. Only 2 per cent. of the typed strains were identified as $M$. fermentans. The latter species was not revealed in any of the patients with balanoposthitis or balanitis erosiva.

$T$-strains As is also shown in Table V, the first attempt at cultivation revealed these strains in $46 \cdot 4$ per cent. of the patients with NGU, in 35 per cent. of those with gonorrhoea, and in $22 \cdot 2$ per cent. of those with balanoposthitis. The isolation rates in control Groups 1 and 2 were roughly the same, viz. 54.3 and 58.3 per cent., while the figures for control Groups 3 and 4 were 25 and $37 \cdot 1$ per cent.

In this connexion it is of interest to note that the findings in the groups expected to be closest to the patient groups with regard to social condition and standards of hygiene (Groups 1 and 2) differ significantly from those in the groups of physicians and medical students (Groups 3 and 4) with isolation rates of 56.4 per cent. of 99 subjects versus 33 per cent. of 51 subjects $(0.01>P>0 \cdot 001)$.

In the study of patients in the NGU group we took a special interest in the duration of symptoms before the first consultation. This varied between 1 day and 2 months, except in one patient who stated that he had had symptoms for "several years". No correlation was revealed between the duration of symptoms and the isolation rates of $T$-strains.

Of the NGU patients, seventeen had a past history of gonorrhoea. T-strains were demonstrated in seven

TABLE V

ISOLATION RATES OF MYCOPLASMATA FROM PATIENTS AND CONTROLS

\begin{tabular}{|c|c|c|c|c|c|c|c|c|c|c|c|c|c|c|}
\hline & \multirow[b]{2}{*}{ Groups Studied } & \multirow[b]{2}{*}{$\begin{array}{l}\text { No. of } \\
\text { Patients }\end{array}$} & \multicolumn{4}{|c|}{ T-strains } & \multicolumn{4}{|c|}{$\begin{array}{l}\text { Classic Mycoplasmata } \\
\text { (Large-colony strains) }\end{array}$} & \multicolumn{4}{|c|}{$\begin{array}{l}\text { Coincidence of } T \text {-strains } \\
\text { and Classic Mycoplasmata }\end{array}$} \\
\hline & & & $\begin{array}{c}\text { First } \\
\text { Culture } \\
\text { positive }\end{array}$ & $\begin{array}{c}\text { Per } \\
\text { cent. }\end{array}$ & $\begin{array}{l}\text { At least } \\
1 \text { of } 3 \\
\text { Cultures } \\
\text { positive }\end{array}$ & $\begin{array}{c}\text { Per } \\
\text { cent. }\end{array}$ & $\begin{array}{c}\text { First } \\
\text { Culture } \\
\text { positive }\end{array}$ & $\begin{array}{c}\text { Per } \\
\text { cent. }\end{array}$ & $\begin{array}{l}\text { At least } \\
1 \text { of } 3 \\
\text { Cultures } \\
\text { positive }\end{array}$ & $\begin{array}{c}\text { Per } \\
\text { cent. }\end{array}$ & $\begin{array}{c}\text { First } \\
\text { Culture } \\
\text { positive }\end{array}$ & $\begin{array}{c}\text { Per } \\
\text { cent. }\end{array}$ & $\begin{array}{l}\text { At least } \\
1 \text { of } 3 \\
\text { Cultures } \\
\text { positive }\end{array}$ & $\begin{array}{l}\text { Per } \\
\text { cent. }\end{array}$ \\
\hline \multirow{3}{*}{ Patients } & $\begin{array}{l}\text { I. Non-gonococcal } \\
\text { urethritis }\end{array}$ & 56 & 26 & $46 \cdot 4$ & 31 & $55 \cdot 4$ & 11 & $19 \cdot 6$ & 14 & $25 \cdot 0$ & 9 & $16 \cdot 1$ & 10 & $17 \cdot 9$ \\
\hline & II. Gonorrhoea & 60 & 21 & $\overline{35 \cdot 0}$ & 29 & $48 \cdot 3$ & 16 & $26 \cdot 7$ & 20 & $33 \cdot 0$ & 7 & $\overline{11 \cdot 7}$ & 9 & $15 \cdot 0$ \\
\hline & $\begin{array}{l}\text { III. Balano- } \\
\text { posthitis }\end{array}$ & 9 & 2 & $22 \cdot 2$ & 2 & $22 \cdot 2$ & 3 & $33 \cdot 3$ & 4 & $44 \cdot 4$ & 2 & $22 \cdot 2$ & 2 & $22 \cdot 2$ \\
\hline \multirow{4}{*}{ Controls } & 1. Healthy contacts & 46 & 25 & $54 \cdot 3$ & 30 & $65 \cdot 2$ & 17 & $37 \cdot 0$ & 20 & $43 \cdot 3$ & 14 & $30 \cdot 4$ & 19 & $41 \cdot 3$ \\
\hline & 2. Service recruits & 53 & 31 & $\overline{58 \cdot 5}$ & & & 5 & $9 \cdot 4$ & & & 4 & $7 \cdot 5$ & & \\
\hline & 3. Physicians, etc. & 16 & 4 & $25 \cdot 0$ & & & 0 & & & & 0 & & & \\
\hline & 4. Medical students & 35 & 13 & $\overline{37 \cdot 1}$ & & & 3 & $8 \cdot 6$ & & & 3 & $8 \cdot 6$ & & \\
\hline
\end{tabular}


of these ( $41 \cdot 2$ per cent.). There thus seemed to be no difference in the occurrence of $T$-strains in NGU patients with previous gonorrhoea and in those with no history of gonorrhoea.

It was not possible to demonstrate any correlation between the amount of urethral discharge and its content of epithelial and pus cells on the one hand and the occurrence of $\mathrm{T}$-strains on the other.

Simultaneous occurrence of large-colony strains and $\mathrm{T}$-strains was revealed at the first attempt at cultivation in $16 \cdot 1$ per cent. of the patients with NGU, in 11.7 per cent. of those with gonorrhoea, and in $22 \cdot 2$ per cent. of those with balanoposthitis. The corresponding figures for the four control Groups were $30 \cdot 4,7 \cdot 5,0$, and $8 \cdot 6$ per cent. respectively.

Table $\mathrm{V}$ shows that, in some of the patients, up to three attempts at cultivation were performed at intervals of from 3 to 14 days. As might be expected, this resulted in somewhat higher isolation rates $(20-$ 25 per cent.) of both classic mycoplasmata and $T$-strains, but this did not appreciably influence the distribution in the various groups studied.

\section{Relation between Therapy and Occurrence of Mycoplasmata}

Of the patients with NGU, 51 were followed clinically and by isolation experiments for 1-6 weeks after the first investigation. Of these, 34 stated that they felt in good health at the last examination, although no treatment had been given. Among these 34 patients, nineteen had $T$-strains associated with NGU, and it should be noted that in eleven the disappearance of symptons was accompanied by failure to isolate $T$-strains. Three patients were cured by treatment with tetracycline, $250 \mathrm{mg}$. four times daily for 6 days. Only in one of these was it possible to isolate a $\mathrm{T}$-strain. At an examination one month later, this strain could no longer be recovered, but urethral discharge had recurred, and classic mycoplasmata, which had also been demonstrated at the first investigation, were still present. One patient with a $\mathrm{T}$-strain was found to have been cured after treatment with Sulfuno R (Sulfanoxolum NFN), and at the same time the T-strain had disappeared.

At the final examination, thirteen patients stated that they still had urethral discharge; six of them had previously harboured $T$-strains, and in four they were still present, but all thirteen failed to appear for further check-ups.

All the patients with gonorrhoea were at the first examination treated with an injection of 600,000 units procaine penicillin, sometimes supplemented with $1,000,000$ units sodium penicillin, but this did not seem to have influenced the isolation rate of T-strains.

Trichomonas vaginalis The investigations of patient Groups I, II, and III and control Group 1 also involved attempted demonstration of Trichomonas vaginalis, but, with the technique used, this proved impossible in all cases.

\section{Discussion}

Several authors (Nicol and Edward, 1953; Freundt, 1956; Klieneberger-Nobel, 1959; Ford and DuVernet, 1963; and others) have reported that they found no definite causal relationship between classic mycoplasmata and NGU, and expressed the view that the organisms were part of the normal bacterial flora of the genito-urinary tract. Our investigations point in the same direction. Like Freundt and Ford we found more positive results in those control groups (1 and 2) which corresponded most closely to the NGU group than in the NGU patients. A slightly higher isolation rate was also achieved in the gonorrhoea group than in the patients with NGU (27 per cent. and 20 per cent., respectively). Like Freundt (1956), we found no evidence to support the opinion of Ruiter and Wentholt (1952), that $M$. fermentans is confined to ulcerative lesions of the glans penis.

The higher isolation rates in control Groups 1 and 2 compared with that in the patients observed in this study militates against the acceptance of a causal relationship between the finding of $\mathrm{T}$-strains in the urethra and the occurrence of NGU in men. This is partially at variance with the results of earlier investigations (cf. Table I), although, as already stated, a significantly higher frequency of $\mathrm{T}$-strains in NGU patients was revealed in only one of these (Csonka and others, 1966). Even though crucial importance can scarcely be attached to the failure of development of circulating antibodies in superficial mucosal infections, it is, nevertheless, of interest to note that Ford (1967), by means of the metabolic inhibition test, demonstrated a significant rise in titre against the homologous strain in only one of eleven NGU cases with T-strains, and that no inhibitory antibodies at all were disclosed in nine of them.

In comparing various studies of NGU and the evaluation of varying results of cultivation, it must be taken into account that NGU, as was pointed out by Harkness and Henderson-Begg (1948), is not a well-defined disease. These authors tried to delineate various forms of NGU on the basis of microscopic and urethroscopic findings. Comparative studies of patients selected on this basis would be 
desirable, but it would be difficult to collect suffciently large series of patients within the different categories.

Although some of the aforementioned authors did not specify their clinical findings in NGU, most of them stated that their NGU patients had mucopurulent or purulent urethral discharge, sometimes associated with moderate dysuria, of a duration varying from a few days to a couple of months. We used similar criteria in the selection of our patients, and our series should, in this respect, be roughly comparable to those considered in previous publications. A few investigators attempted to distinguish between abacterial and bacterial varieties of urethritis and to correlate the incidence of $T$-strains with the amount of urethral discharge. We made a similar attempt, but were unable to demonstrate any significant differences.

The technique used by us in the collection of urethral discharge differs to some extent from that recommended by most other authors; we used a cotton swab instead of a platinum loop. The swab method is routinely used in our department and is also more acceptable to the controls. That the results obtained by the two methods do not differ materially appears from a comparative study performed by Ford and DuVernet (1963).

Judging from the results in Table II, the transport medium used by us seems to be at least as good as Stuart's transport medium, which was employed by Csonka and others (1966).

As distinct from other authors, we regularly used three different media for the isolation of $T$-strains. In this way we obtained, as appears from Table IV, a higher total isolation rate than would have been secured by the use of only one of the three media. Omission of thallium acetate would have resulted in complete or partial bacterial overgrowth in many of the cultures, which would have rendered reading and isolation difficult. But since thallium acetate exerts a certain inhibitory influence on the $T$-strains (Shepard and Lunceford, 1967), though not on classic mycoplasmata, it is necessary to include a medium which contains penicillin as the only bacteriostatic agent.

Concerning the influence of methods of cultivation on the results, it seems reasonable to point out that Csonka and others (1966) cultured specimens of urethral discharge from their patients, whereas they used urine as the only source for isolation in their control group. In view of our low rates of isolation of $\mathrm{T}$-strains from urine, it is possible that this difference in source of material for culture accounts for their being the only authors to have found a significantly higher incidence of T-strains in NGU patients than in healthy subjects.

In early reports by Melén and Linnros (1952), Shepard (1954), and Klieneberger-Nobel (1959), attention was drawn to the widely varying results of cultivation for mycoplasmata obtained when studying control subjects with different social and hygienic standards. Their views were confirmed by the results in our controls comparable as regards age, in which a statistically significant difference was seen between control Groups 1 and 2 (healthy contacts and service recruits) who must largely be assumed to represent a relatively low social and hygienic level, and control Groups 3 and 4 (physicians and medical students) who represent a higher social and hygienic standard. It is interesting to note that Ingham and others (1966), in studying a control group consisting of "men seeking reassurance that they had not contracted venereal disease as the result of sexual exposure", found T-strains in 48 per cent. This group is very similar to our control Group 1, representing healthy persons who had had sexual contact with patients with gonorrhoea, in which we obtained an almost identical isolation rate, viz. 54 per cent.

On the basis of the study reported here, we cannot give any opinion as to the possible effect of the broad-spectrum antibiotics on $\mathrm{T}$-strain-associated NGU. We have had an opportunity to follow only one patient with this type of NGU for 1 month after treatment with tetracycline. Our reluctance to give treatment to patients who are frequently sexual contacts of persons infected with Neisseria gonorrhoeae, arises from our wish to obtain the results of three consecutive examinations for gonorrhoea, performed at intervals of 1 week, before any antibiotic treatment is instituted. However, this has provided an opportunity to follow some patients who were left untreated for 2 to 4 weeks, by which time we observed that 67 per cent. became symptom-free without treatment, and that in some cases the $T$ strains disappeared at the same time.

It is obvious that in these circumstances it may be difficult to assess the effect of antibiotic therapy on NGU. Accordingly, we find that the demonstration of the sensitivity of T-strains to tetracycline (Ford, 1962) and the observation of an apparent therapeutic effect of this antibiotic on NGU (Shepard and others, 1964) do not justify the conclusion that Tstrains are aetiologically important in this disease. Further experiments with placebo medication to control groups are required.

\section{Summary}

125 male patients and 150 male controls were studied to determine the occurrence of classic myco- 
plasmata and $\mathrm{T}$-strains in the urethral secretions. The patients included 56 with NGU, sixty with gonorrhoea, and nine with balanoposthitis and balanitis erosiva.

The controls included 46 healthy contacts of the patient group, 53 service recruits, sixteen physicians and technicians from our departments, and 35 medical students.

Classic mycoplasmata were demonstrated in $19 \cdot 6$ per cent. of the patients with NGU, in 26.7 per cent. of those with gonorrhoea, and in 37 per cent. in the control group which best corresponded to the patient groups. The distribution of positive findings in the various groups did not support the assumption that classic mycoplasmata play an aetiological role in NGU. The isolated typed strains were $\mathrm{Myco-}$ plasma hominis in 98 per cent. and Mycoplasma fermentans in 2 per cent.

T-strains were isolated in $46 \cdot 6$ per cent. of the 56 patients with NGU, in 35 per cent. of the sixty patients with gonorrhoea, and in 54.3 per cent. of the 46 healthy contacts of the gonorrhoea patients.

No correlation was observed between the duration or severity of the various symptoms and the occurrence of $\mathrm{T}$-strains.

The differences between the present results and those previously reported are discussed.

Our findings did not support the notion of a causal relationship between the occurrence of $\mathrm{T}$-strains and NGU.

Before the problem can be solved, it is necessary to await, inter alia, serological typing of the isolated strains and to study the distribution of the various sero-types within patient and control groups.

This study was supported by grants from P. Carl Petersens Fond and F. L. Smidth \& Co. A/S's Jubilæumsfond.

\section{REFERENCES}

Csonka, G. W., Williams, R. E. O., and Corse, J. (1966). Lancet, 1, 1292.

Dienes, L., and Edsall, G. (1937). Proc. Soc. exp. Biol. $(N . Y), 36,$.740 .

Ford, D. K. (1962). F. Bact., 84, 1028.

- (1967). Ann. N.Y. Acad. Sci., 143, Art. 1, p.501.

and DuVernet, M. (1963). Brit. F. vener. Dis., 39, 18.

- and Macdonald, J. (1963). F. Bact., 85, 649.

二, Rasmussen, G., and Minken, J. (1962). Brit. F. vener. Dis., 38, 22.

Freundt, E. A. (1954). Acta path. microbiol. scand., 34, 127.

- (1956). Brit, f. vener. Dis., 32, 188.

Harkness, A. H., and Henderson-Begg, A. (1948). Ibid., 24, 50 .

Ingham, H. R., Macfarlane, W. V., Hale, J. H., Selkon, J. B., and Codd, A. A. (1966). Ibid, 42, 269.
Klieneberger-Nobel, E. (1959). Brit. med.f., 1, 19.

Melén, B., and Linnros, B. (1952). Acta derm.-venereol. (Stockh.), 32, 77.

Nicol, C. S., and Edward, D. G. ff. (1953). Brit. F. vener. Dis., 29, 141.

Ruiter, M., and Wentholt, H. M. M. (1952). F. invest. Derm., 18, 313.

Salaman, M. H., King, A. J., Bell, H. J., Wilkinson, A. E., Gallagher, E., Kirk, C., Howorth, I. E., and Keppich, P. H. (1946). F. Path. Bact., 58, 31.

Shepard, M. C. (1954). Amer. F. Syph., 38, 113. (1956). F. Bact., 71, 362.

(1959). Urol. int., 9, 252.

, Alexander, C. E., Lunceford, C. D., and Campbell,

P. E. (1964). F. Amer. med. Ass., 188, 729.

- and Lunceford, C. D. (1967). F. Bact., 93, 1513.

\section{La présence des souches $\mathbf{T}$ de mycoplasmes dans l'urétrite non-blennorragique}

\section{RÉsuMé}

125 hommes malades et 150 hommes contrôles ont été étudiés afin de déterminer la présence des mycoplasmes classiques et ceux des souches $\mathrm{T}$ dans les sécretions urétrales. Les malades comprenaient 56 atteints d'urétrite non-blennorragique, 60 atteints de blennorragie et 9 atteints de balano-posthite et de balanite érosive.

Les contrôles comprenaient $\mathbf{4 6}$ contacts sains du même groupe que les malades, 53 recrues des forces armées, 16 médecins et techniciens de nos services, et 35 étudiants en médecine.

Des mycoplasmes classiques ont été démontrés chez 19,6 pour cent des malades atteints d'urétrite nonblennorragique, chez 26,7 pour cent de ceux atteints de blennorragie, et chez 37 pour cent du groupe des contrôles qui correspondaient le mieux au groupe des malades. La distribution des résultats positifs dans les divers groupes n'avait pas permis d'assumer que les mycoplasmes classiques jouent un role étiologique dans l'urétrite non-blennorragique. Les souches qui ont été isolées et identifiées étaient le mycoplasma hominis dans 98 pour cent et le mycoplasma fermentans dans 2 pour cent des cas.

Les souches $T$ avaient été isolées chez 46,6 pour cent des 56 malades atteints d'urétrite non-blennorragique, chez 35 pour cent des 60 malades atteints de blennorragie et chez 54,3 pour cent des 46 contacts sains des malades atteints de blennorragie.

Aucune corrélation n'avait été observée entre la durée et la sévérite des différents symptômes et la présence des souches $T$.

Les différences entre ces résultats et ceux rapportés précédemment sont discutées.

Nos observations n'avaient pas corroboré la notion de cause à effet entre la présence des souches $T$ et l'urétrite non-blennorragique.

Avant que le problème puisse être résolu, il serait nécessaire d'attendre, inter alia, l'identification sérologique des souches isolées et d'étudier la distribution des différents types sérologiques chez le groupe des malades et celui des contrôles. 